\title{
A comparison of bioclimatic conditions on Franz Josef Land (the Arctic) between the turn of the nineteenth to twentieth century and present day
}

\author{
Andrzej Araźny ${ }^{1}$ (D) Przemysław Wyszyński ${ }^{1} \cdot$ Rajmund Przybylak $^{1}$
}

Received: 21 May 2018 / Accepted: 21 December 2018 / Published online: 10 January 2019

(C) The Author(s) 2019

\begin{abstract}
The paper presents the variability of meteorological conditions: air temperature, wind speed and relative air humidity; and biometeorological indices: wind chill temperature, predicted clothing insulation and accepted level of physical activity on Franz Josef Land (in Teplitz Bay and Calm Bay) in the years 1899-1931. It employs meteorological measurements taken during four scientific expeditions to the study area. The analysis mainly covered the period October-April, for which the most complete data set is available. For that period of the year, which includes the part of the year with the Franz Josef Land's coldest air temperatures, the range and nature of changes in meteorological and biometeorological conditions between historical periods and the modern period (1981-2010) were studied. The data analysis revealed that during the three oldest expeditions (which took place in the years 1899-1914), the biometeorological conditions in the study area were more harsh to humans than in the modern period (1981-2010) or similarly harsh. In contrast, during the 1930/1931 expedition, which represents the Early Twentieth Century Warming (ETCW), conditions were clearly more favourable (including predicted clothing insulation being 0.3 clo lower and $4.0{ }^{\circ} \mathrm{C}$ higher wind chill temperature than conditions observed nowadays).
\end{abstract}

\section{Introduction}

Over the last few centuries, conditions for human habitation have dramatically changed. The atmosphere and oceans have warmed, sea levels have risen and the amount of snow and ice has dropped around the world and the Arctic is a global 'hot point' that is heating up faster than any other region in the world (IPCC 2013). The Arctic plays a key role in the shaping of the climate at lower latitudes (Serreze and Barry 2014; Przybylak 2016; Przybylak and Wyszyński 2017). The Arctic (more precisely, the Arctic circle), where the impact of cold and wind is a daily risk, is home to more than 4 million people (e.g. Gavhed 2003; ACIA 2005; Araźny 2008; Maciejczyk et al. 2017).

Electronic supplementary material The online version of this article (https://doi.org/10.1007/s00704-018-02763-y) contains supplementary material, which is available to authorized users.

Andrzej Araźny

andy@umk.pl

1 Department of Meteorology and Climatology, Nicolaus Copernicus University, Lwowska 1, 87-100 Torun, Poland
The oldest instrumental meteorological data from Franz Josef Land (FJL) were collected during an expedition led by Luigi Amadeo di Savoia (wintering at Teplitz Bay in 1899/1900) (Cagni 1903), Anthony Fiala (Teplitz Bay, 1903/1904) (Peters and Fleming 1907), Georgiy Yakovlevich Sedov (Calm Bay, 1913/1914) (Vise 1933) and by the Section for Polar and High Altitude Observations of the Central Geophysical Observatory in St Petersburg (Calm Bay, 1930/1931) (Lvov 1933). Many works exist that describe the history of discoveries on FJL and the course of exploratory expeditions in the region (e.g. Capelotti 2009, 2016), but daily and sub-daily resolution data gathered during those expeditions have thus far not been subjected to detailed study. The exceptions are the works of Przybylak et al. (2010, 2013), which analysed only monthly air temperature and atmospheric pressure values on FJL in the historical periods, i.e. in the nineteenth century and the beginning of the twentieth.

The present paper describes the meteorological and biometeorological conditions at the turn of the nineteenth to twentieth century during the expeditions cited above and then compares them with the contemporary period. It uses meteorological data from the Ostrov Heisa meteorological station for 1981-2010 (http://meteo.ru/). The climatic conditions for the last several decades in FJL have been thoroughly investigated 
(e.g. Hisdal 1995; Przybylak 2016; Shilovtseva and Romanenko 2016). However, there is a lack of information about the meteorological and biometeorological conditions for earlier periods. One of the first works to describe the biometeorological conditions of the Arctic in the historical period is the article by Araźny (2010). In it, the author presents the spatial biometeorological conditions for the entire Arctic but only during the First International Polar Year, 1882/83. The present article aims to present the biometeorological conditions at a regional scale, focusing on their changes over time, i.e. from the historical period spanning the turn of the nineteenth to twentieth century, including the years of the Early Twentieth Century Warming (ETCW) to the modern period (1981-2010).

\subsection{Area, data and methods}

Until the latter half of the nineteenth century, FJL was an unknown territory. It was discovered during attempts to find the Northeast Passage. In the years 1872-4, this area was discovered and initially investigated by an Austro-Hungarian expedition led by Weyprecht and Payer (Williams 2005).
The FJL archipelago is located in the northwest of the Barents Sea (Fig. 1). The archipelago is comprised of 191 islands with a combined area of $16,135 \mathrm{~km}^{2}$. FJL is located between $79^{\circ} 46^{\prime}$ and $81^{\circ} 52^{\prime} \mathrm{N}$ and $44^{\circ} 52^{\prime}$ and $65^{\circ} 25^{\prime} \mathrm{E}$ and stretches $375 \mathrm{~km}$ from west to east and $234 \mathrm{~km}$ from south to north. At $81^{\circ} \mathrm{N}$, the period in which the sun (the whole solar disc) remains continuously above the horizon (midnight sun) starts on about 12th April and ends around 30th August, i.e. 141 days in all. The period in which the whole solar disc is continuously below the horizon (polar night) lasts from about 19th October to about 23rd February or 128 days in all (Hisdal 1995). Widespread glaciers predominate in the archipelago, covering $85 \%$ of the total land area (e.g. Grosswald et al. 1973; Glazovskij 1995). Most glaciers end in cliffs in the waters of straits and fjords. The summits of many large ice caps lie at around $500 \mathrm{~m}$ a.s.l. (metres above sea level), with the highest at about $650 \mathrm{~m}$ a.s.l. (Grosswald et al. 1973; Lubinski et al. 1999).

To assess meteorological and biometeorological conditions, average diurnal values were used. They were calculated on the basis of fixed hour values (Table 1). Data from four historical expeditions (Teplitz Bay, 1899/1900; Teplitz Bay, 1903/1904; Calm Bay, 1913/1914 and Calm Bay,

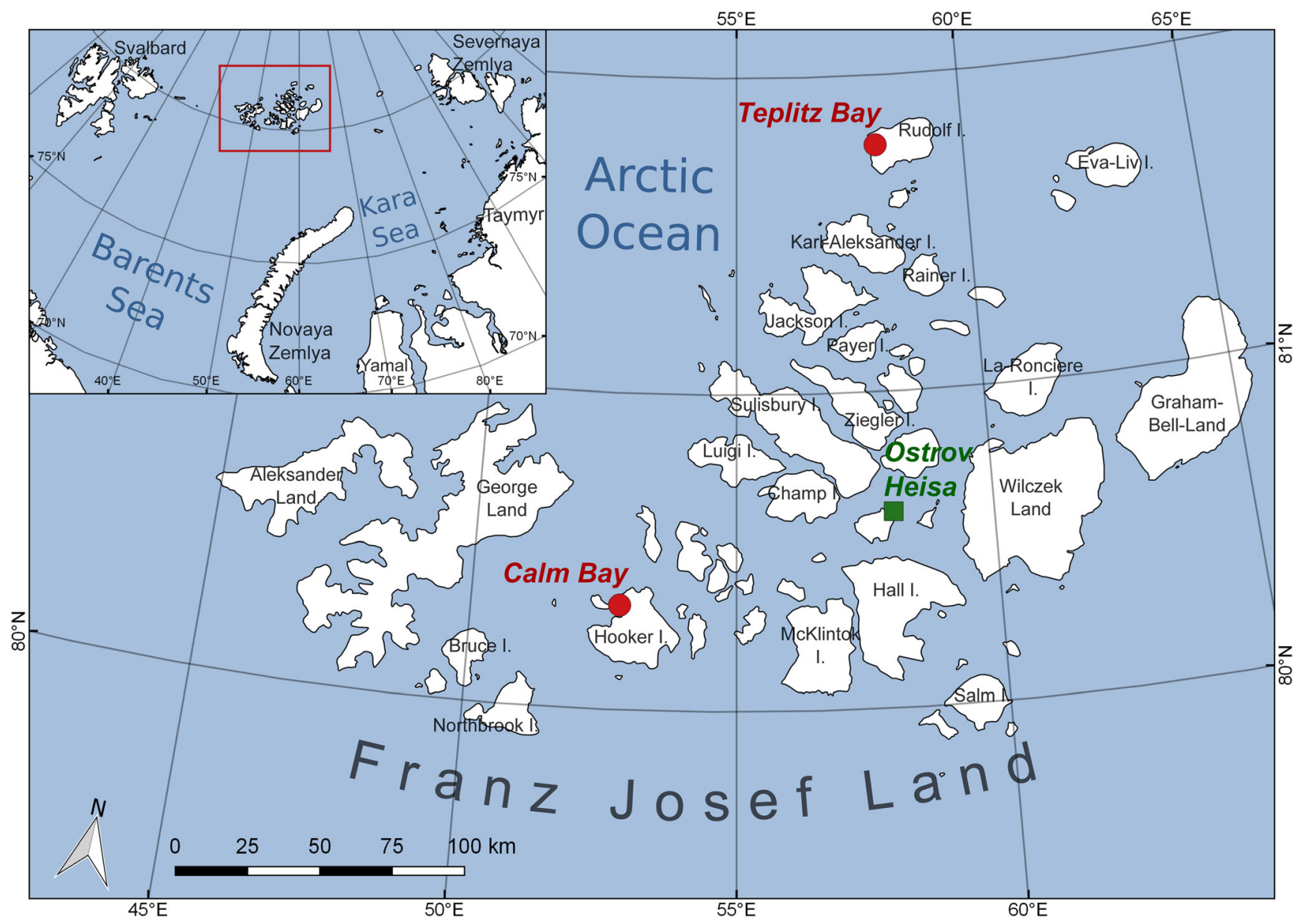

Fig. 1 Location of historical (dots) and modern (square) land meteorological stations in Franz Josef Land 
Table 1 Geographic location of historical and present-day stations in Franz Josef Land. Temporal usage, resolution and sources of raw data for wind speed $(\mathrm{V})$, air temperature $(\mathrm{T})$ and relative air humidity $(\mathrm{RH})$

\begin{tabular}{|c|c|c|c|c|c|c|c|c|}
\hline Station & Latitude & Longitude & $\begin{array}{l}\text { Station } \\
\text { elevation } \\
\text { (m a.s.1.) }\end{array}$ & Temporal data usage & Source of data & $\mathrm{V}\left(\mathrm{m} \mathrm{s}^{-1}\right)$ & $\mathrm{T}\left({ }^{\circ} \mathrm{C}\right)$ & $\mathrm{RH}(\%)$ \\
\hline Teplitz Bay & $81.78^{\circ} \mathrm{N}$ & $58.07^{\circ} \mathrm{E}$ & 4.1 & 1899.08.01-1900.08.31 & Cagni 1903 & $\mathrm{~h}$ & $\mathrm{~h}$ & $\mathrm{~h}$ \\
\hline Teplitz Bay & $81.78^{\circ} \mathrm{N}$ & $58.07^{\circ} \mathrm{E}$ & 9.3 & 1903.09.01-1904.04.30 & $\begin{array}{l}\text { Peters and } \\
\quad \text { Fleming } 1907\end{array}$ & $8,12,20 \mathrm{LMT}$ & 8, 12, $20 \mathrm{LMT}$ & - \\
\hline $\begin{array}{l}\text { Calm Bay (Buhta } \\
\text { Tikhaya) }\end{array}$ & $80.32^{\circ} \mathrm{N}$ & $52.80^{\circ} \mathrm{E}$ & 5.9 & 1913.09.01-1914.07.31 & Vise 1933 & $2 \mathrm{~h}$ & $\mathrm{~h}$ & $2 \mathrm{~h}$ \\
\hline $\begin{array}{l}\text { Calm Bay (Buhta } \\
\text { Tikhaya) }\end{array}$ & $80.32^{\circ} \mathrm{N}$ & $52.80^{\circ} \mathrm{E}$ & 5.9 & 1930.08.01-1931.07.31 & Lvov 1933 & 7, 13, $21 \mathrm{LMT}$ & $\mathrm{h}$ & $\mathrm{h}$ \\
\hline Ostrov Heisa & $80.62^{\circ} \mathrm{N}$ & $58.05^{\circ} \mathrm{E}$ & 20.0 & 1981.01.01-2010.12.31 & $\begin{array}{l}\text { RIHMI-WDC, } \\
\text { http://meteo.ru }\end{array}$ & $\mathrm{t}$ & $\mathrm{t}$ & $\mathrm{t}$ \\
\hline
\end{tabular}

h, every hour; $2 \mathrm{~h}$, every $2 \mathrm{~h}(0,2,4,6,8,10,12,14,16,18,20,22 \mathrm{LMT})$; t, six times a day $(0,3,6,9,12,12,15,18,21$ LMT); RIHMI-WDC, All-Russia Research Institute of Hydrometeorological Information-World Data Centre

1930/1931) were transcribed from source materials (see Table 1) and digitised for the present paper. Such an approach guarantees the lowest error rates when acquiring data from antique books and prints (Brönnimann et al. 2006). All outliers were checked and suspect ones removed after inspection from the data set, similarly as was done for other studies (Przybylak et al. 2010, 2016; Przybylak and Wyszyński 2017). The rest were quality controlled by the national Russian meteorological service before being published. The locations of sites for which meteorological and biometeorological data are available, and their time coverage are shown in Table 1. The state of completeness of the historical meteorological data led to the October-April period (hereafter winter) being selected. On average, this period has the lowest air temperatures in the course of a year.

To explain the general meteorological conditions during the analysed four historical periods (Table 1) in the FJL area, the distribution of atmospheric pressure patterns and atmospheric circulation were analysed on the basis of the Twentieth Century Reanalysis Project (20CRv2c, Compo et al. 2011).

Meteorological conditions are presented using air temperature, relative humidity and wind speed, which are essential for calculating the biometeorological indices proposed in the paper. The analysis of both meteorological and biometeorological conditions was performed using standard methods used in climatology (Gregory 1973) and bioclimatology (Błażejczyk and Kunert 2011).

Apparent conditions are presented using three biometeorological indices: wind chill temperature (WCT); insulation predicted (Iclp), which measures the predicted insulating value of clothing; and accepted level of physical activity (MHR). These indices were calculated using BioKlima 2.6 software (Błażejczyk 2017).

For calculation of biometeorological indices (Iclp and MHR) on FJL, wind speeds were reduced from the measurement height above ground level to the height of the human torso. The International Society of Biometeorology recommends the standard height of $1.2 \mathrm{~m}$ (Błażejczyk and Kunert 2011). Iclp and MHR were calculated for the wind at $1.2 \mathrm{~m}$ above the ground. Calculations were made according to Milewskij (1960):

$V_{z=} V_{w}\left(h_{z} h_{w}\right)^{0.2}$

where $V_{z}$, wind speed at height $h_{z}=1.2$ or $10 \mathrm{~m}$; $V_{w}$, wind speed at anemometer height $h_{w}$. Wind speed in $\mathrm{m} \mathrm{s}^{-1}$ units.

Meanwhile, WCT was calculated according to the appropriate method for that index, which is the wind speed recorded at $10 \mathrm{~m}$ a.g.l.

Apparent cold and degree of risk of frostbite to the human body on FJL was assessed using wind chill temperature (WCT, in ${ }^{\circ} \mathrm{C}$ ) (Nelson et al. 2002). This index was created based on thermophysiological experiments and theoretical research in Canada and the USA related to the influence of temperature and air movement on apparent conditions in winter. The WCT index is calculated according to the following equation:

$\mathrm{WCT}=13.12+0.6215 \cdot t-11.37 \cdot v_{10} 0.16+0.3965 \cdot t \cdot v_{10}{ }^{0.16}$

where $t$, air temperature $\left(\right.$ in $\left.{ }^{\circ} \mathrm{C}\right) ; \mathrm{v}_{10}$, wind speed at $10 \mathrm{~m}$ a.g.l. (in $\mathrm{m} \mathrm{s}^{-1}$ ).

Based on WCT values, the threat level of meteorological conditions and the threat to human health are assessed (Table 2; see also Błażejczyk and Kunert 2011).

The second biometeorological index used is insulation predicted (Iclp, in clo units). It determines the thermal insulation of clothing required for a person to maintain thermal equilibrium in particular meteorological conditions. It is arrived at using the equation of Burton and Edholm (1955), which determines the total thermal insulation of clothing and the surrounding thin surface air layer, and the equation of 
Table 2 Characteristic of biometeorological conditions based on WCT index

\begin{tabular}{|c|c|c|}
\hline $\mathrm{WCT}\left({ }^{\circ} \mathrm{C}\right)$ & Risk of frostbite & Health concern \\
\hline$>-9.9$ & Low & Slight increase in discomfort. \\
\hline$-10.0 \div-27.9$ & Low & Risk of hypothermia if outside for long periods without adequate protection. \\
\hline$-28.0 \div-39.9$ & Risk & $\begin{array}{l}\text { Exposed skin can freeze in } 10 \text { to } 30 \text { min. Check face and extremities for numbness or whiteness. Risk } \\
\text { of hypothermia if outside for long periods without adequate clothing or shelter from wind and cold. }\end{array}$ \\
\hline$-40.0 \div-47.9$ & High & $\begin{array}{l}\text { Exposed skin can freeze in } 5 \text { to } 10 \mathrm{~min} \text {.* Check face and extremities for numbness or whiteness. Risk } \text { of hypothermia if outside for long periods without adequate clothing or shelter from wind and cold. }\end{array}$ \\
\hline$-48.0 \div-54.9$ & Very high & $\begin{array}{l}\text { Exposed skin can freeze in } 2 \text { to } 5 \text { min.* Check face and extremities frequently for numbness or whiteness. } \\
\text { Serious risk of hypothermia if outside for long periods without adequate clothing or shelter from wind } \\
\text { and cold. }\end{array}$ \\
\hline$\leq-55.0$ & Extremely high & Exposed skin can freeze in less than 2 min.* Danger! Outdoor conditions are hazardous. \\
\hline
\end{tabular}

*In sustained winds of over $50 \mathrm{~km} / \mathrm{h}$, frostbite can occur faster than indicated

Source: http://www.ec.gc.ca/meteo-weather/

Fourt and Hollies (1970), which determines the thermal insulation of the surface layer of air. In this study, Iclp is calculated using the equation provided in Błażejczyk and Kunert (2011):

$\operatorname{Iclp}=\{0.082 \cdot[91.4-(1.8 \cdot t+32)] /(0.01724 \cdot M)\}-\left[1 /\left(0.61+1.9 \cdot v^{0.5}\right)\right]$

where $t$, air temperature (in ${ }^{\circ} \mathrm{C}$ ); $M$, metabolism (in $\mathrm{W} \mathrm{m}^{-2}$ ); $v$, wind speed (in $\mathrm{m} \mathrm{s}^{-1}$ ).

Iclp was calculated assuming a metabolism of $135 \mathrm{~W} \mathrm{~m}^{-2}$ for a person moving outdoors at $4 \mathrm{~km} \mathrm{~h}^{-1}$. With reference to the value of the Iclp index (in clo), the thermal environment assessment scale proposed by Krawczyk (2000) may be used: $\leq 0.30$ very warm, $0.31-$ 0.80 warm, $0.81-1.20$ neutral, $1.21-2.00 \mathrm{cool}, 2.01-3.00$ cold, 3.01-4.00 very cold, $>4.00$ Arctic.

One of the most important physiological characteristics is heart rate (HR), which is the number of heart beats per minute. HR is affected by both physical activity and certain meteorological elements. Pulse increases with an increase in air temperature and water vapour pressure, and increased physical effort. A normal HR for men is 70-72 beats per minute and 78-82 for women (Błażejczyk and Kunert 2011). An increase of HR above 90 beats per minute is accompanied by increased burden on the entire cardiovascular system. Knowing the current meteorological conditions, it is possible to determine the accepted level of physical activity (MHR, in $\mathrm{W} \mathrm{m}^{-2}$ ) which can be undertaken without excessively stressing the heart. The index MHR is calculated using the equation provided in Błażejczyk and Kunert (2011):

$\mathrm{MHR}=[90-22.4-0.25 \cdot(5 \cdot t+2.66 \cdot \mathrm{vp})] / 0.18$

where $t$, air temperature $\left(\right.$ in $\left.{ }^{\circ} \mathrm{C}\right)$; $\mathrm{vp}$, water vapour pressure (in $\mathrm{hPa}$ ).

\section{Results}

\subsection{Air temperature}

Of the climatic stimuli, thermal stimuli are among the most perceptible by humans, which is why they are a fundamental and widely used criterion for assessing weather conditions. Low air temperature with strong wind makes for highly unfavourable conditions for humans, in which significant body heat losses are recorded (e.g. Osczevski 2000; Parsons 2003; Araźny 2008).

At FJL, the average annual air temperature in Ostrov Heisa (hereafter OH) in the modern period (according to the 19812010 climate norm) was $-12.4^{\circ} \mathrm{C}$. In the course of the year, the highest average monthly values $\left(0.7\right.$ and $\left.0.1{ }^{\circ} \mathrm{C}\right)$ were recorded in July and August, respectively, and the lowest $\left(-23.1\right.$ and $\left.-23.0^{\circ} \mathrm{C}\right)$ in February and March, respectively (Table 3 ). Average diurnal air temperatures were significantly more variable. In the years 1981-2010, they ranged from 42.1 to $5.5^{\circ} \mathrm{C}$ (Fig. 2). Additionally, recorded data show that the lowest absolute air temperature on FJL $\left(-48{ }^{\circ} \mathrm{C}\right)$ was recorded in March 1894 (Geographisches Handbuch 1909).

The first three analysed historical series (1899/1900, 1903/ 1904 and 1913/1914) show lower air temperatures than present-day values. Winter (Oct-Apr) in the aforementioned periods was on average $1.8-4.6{ }^{\circ} \mathrm{C}$ cooler (Table 3). In individual months, the highest negative anomalies were identified in Calm Bay (hereafter CB) in January $1914\left(-7.4^{\circ} \mathrm{C}\right)$ and in February $1900\left(-6.8^{\circ} \mathrm{C}\right)$. In contrast, during the $1930 / 31$ expedition, it was $4.6^{\circ} \mathrm{C}$ warmer than the present day in $\mathrm{CB}$ (Table 3). Such a high thermal anomaly was influenced by a warm autumn and winter, especially February 1931, when the average monthly temperature was $10.7^{\circ} \mathrm{C}$ higher than in the modern period. The autumn and winter thermal warming was caused by a strong influx of warm air from the southern sector, as evidenced by an analysis of wind directions and velocities 
Table 3 Average monthly air temperatures $\left({ }^{\circ} \mathrm{C}\right)$ at Ostrov Heisa $(\mathrm{OH})$ in the years 1981-2010, and mean differences between the monthly values on Franz Josef Land for the historical period (for Teplitz Bay [TB] and Calm Bay [CB] stations) and the contemporary period (Ostrov Heisa)

\begin{tabular}{lclllr}
\hline $\begin{array}{l}\text { Station } \\
\text { Month }\end{array}$ & OH 1981-2010 & $\begin{array}{l}\text { TB (1899-1900) minus } \\
\text { OH (1981-2010) }\end{array}$ & $\begin{array}{l}\text { TB (1903-1904) minus } \\
\text { OH (1981-2010) }\end{array}$ & $\begin{array}{l}\text { CB (1913-1914) minus } \\
\text { OH (1981-2010) }\end{array}$ & $\begin{array}{l}\text { CB (1930-1931) minus } \\
\text { OH (1981-2010) }\end{array}$ \\
\hline Aug & 0.1 & & & & 0.1 \\
Sep & -2.7 & -2.6 & $-4.0^{\mathrm{a}}$ & -1.3 & 1.5 \\
Oct & -10.8 & -6.1 & -4.0 & -3.3 & $8.9^{\mathrm{d}}$ \\
Nov & -17.1 & -1.7 & -6.6 & -2.5 & 7.6 \\
Dec & -21.9 & 4.1 & -4.5 & 4.8 & 3.0 \\
Jan & -22.7 & 2.6 & -3.4 & -7.4 & 10.7 \\
Feb & -23.1 & -6.8 & -3.9 & -3.5 & -3.1 \\
Mar & -23.0 & -5.6 & $-5.7^{\mathrm{b}}$ & -3.0 & 3.8 \\
Apr & -18.7 & -0.5 & $-3.9^{\mathrm{c}}$ & 2.2 & -0.6 \\
May & -8.7 & -0.9 & & 0.5 & -0.6 \\
Jun & -1.4 & 0.1 & & -0.1 & 0.6 \\
Jul & 0.7 & 1.6 & -4.6 & -1.8 & 0.7 \\
Oct-Apr & -19.6 & -2.0 & & & 4.6 \\
\hline
\end{tabular}

-, no data; a, 1 Sep; b, 7-11 Mar; c, 30 Apr; d, 10-15 Nov

based on data from the 20CRv2c reanalysis (Fig. 3, Compo et al. 2011). Average diurnal air temperatures were within two standard deviations (2SD) of the 1981-2010 average (Fig. 4).

\subsection{Wind speed}

Wind speed is one of the most important mechanical stimuli affecting the human body. In the Arctic, strong winds at low temperatures can interfere with the human heat balance (Araźny et al. 2010). Air movement affects humans both acoustically and mechanically (Bottema 2000), and is an equally important factor as air temperature and solar radiation in shaping the subjective feeling of thermal comfort or discomfort (Błażejczyk 2004; Błażejczyk and Kunert 2011).

Average wind speed in the modern period was $3.7 \mathrm{~m} \mathrm{~s}^{-1}$ at $\mathrm{OH}$ (at a height of $1.2 \mathrm{~m}$ a.g.1.). Over the course of the year, the highest wind speeds on FJL occur in winter and the lowest in summer (Table 4, Fig. 5). The highest average monthly wind speed at $\mathrm{OH}$ occurred in January and September $\left(4.2 \mathrm{~m} \mathrm{~s}^{1}\right)$ and the lowest $\left(3.0 \mathrm{~m} \mathrm{~s}^{1}\right)$ in August. Average diurnal wind speeds are more variable, particularly in winter, with a maximum of $16.0 \mathrm{~m} \mathrm{~s}^{-1}$.

Wind speed and direction are influenced by the type of baric regime and its location (see supplementary Fig. S1). Wind parameters are greatly modified by local topography, which is why they differ significantly from one FJL station to another. Wind speeds significantly weaker (by $2.1 \mathrm{~m} \mathrm{~s}^{1}$ ) than those recorded in modern winters were found during the expedition in Teplitz Bay (hereafter TB) 1899-1900 (Table 4, Fig. 5). In this period, the dynamics of air mass flows over FJL was poor (Fig. 3). In contrast, during the other three expeditions, higher wind speeds were recorded. Particularly, high wind speeds (of $2.2 \mathrm{~m} \mathrm{~s}^{-1}$ faster) occurred in CB in 1930/31. One characteristic feature of winters from the period 1920 1940 in the Arctic was the increasing pressure difference between Spitsbergen and the northern coast of Norway
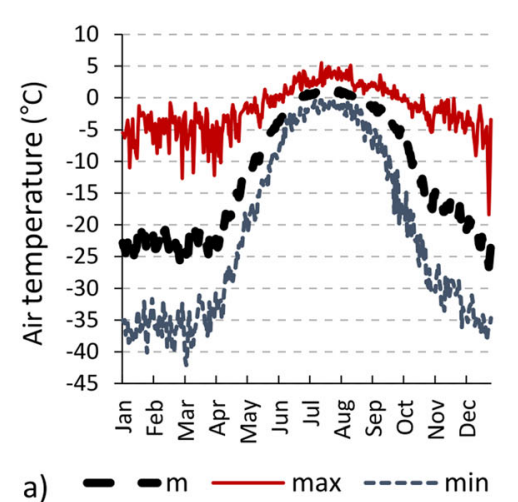

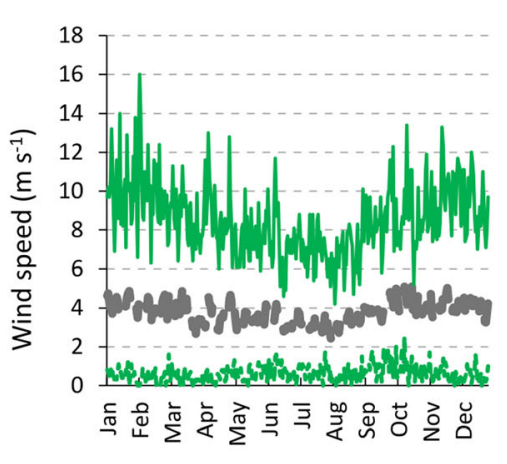

b) $-m-\max -----\min$

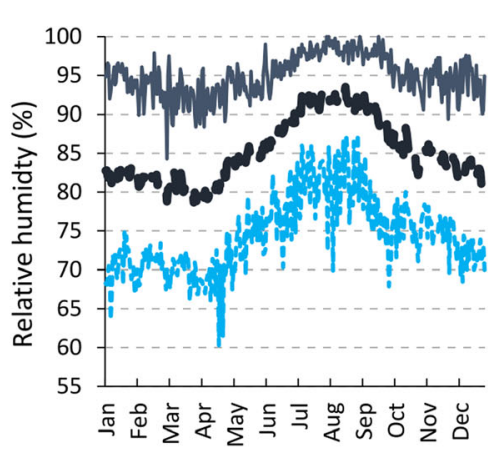

c) $-m-\max -----\min$

Fig. 2 Annual course of air temperature, wind speed (1.2 $\mathrm{m}$ a.g.1.) and relative humidity according to average diurnal values in Ostrov Heisa in the years 1981-2010. m, average diurnal value; max, highest diurnal average; min, lowest diurnal average 


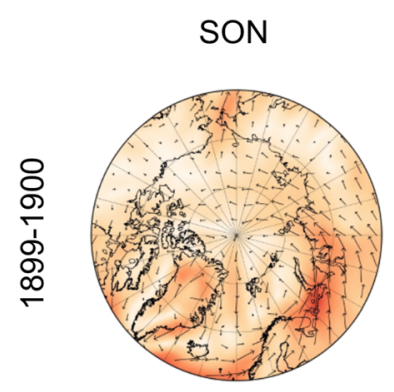

DJF
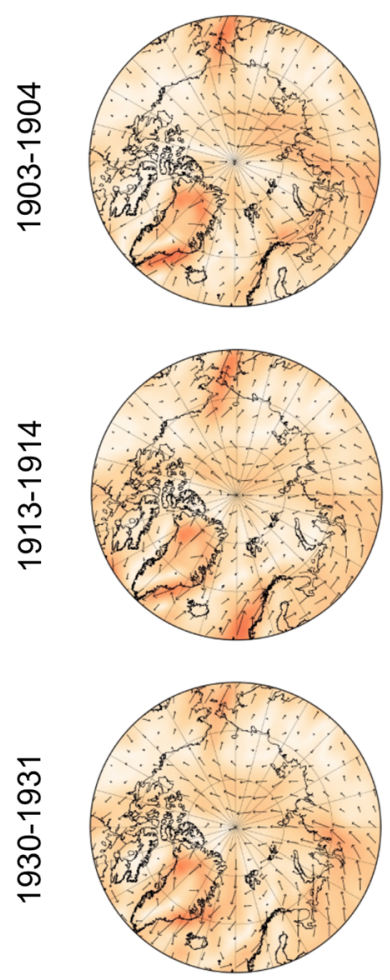

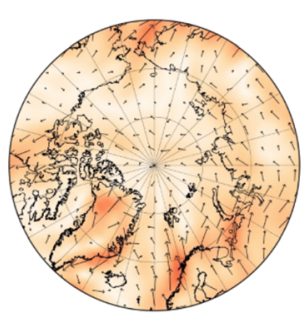

MAM
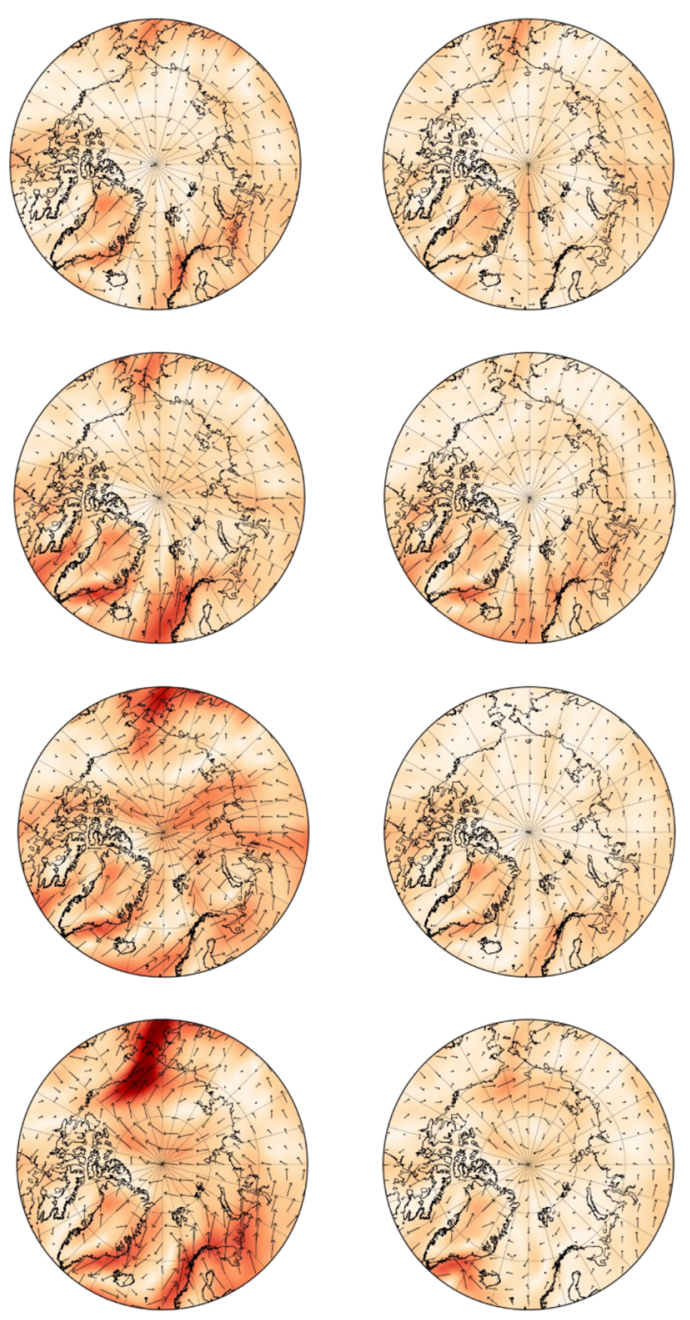

JJA
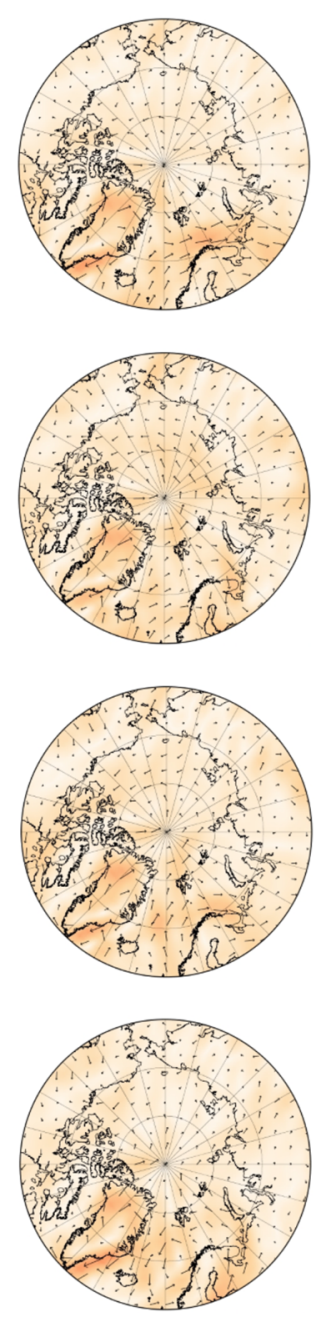

Fig. 3 Seasonal (SON, DJF, MAM, JJA) spatial distribution of directions and velocities $\left(\mathrm{m} \mathrm{s}^{-1}\right)$ of air mass flows in the Arctic $\left(>60^{\circ} \mathrm{N}\right)$ for 1899 1900, 1904-1905, 1913-1914 and 1930-1931. Calculations based on u-

(Bengtsson et al. 2004). This is confirmed by the large pressure gradient (Fig. S1) between the powerful Siberian High and the low pressure system over the Barents Sea in the winter of 1930/31. This can be taken as the explanation for the high wind speeds (particularly in winter) at CB in 1930/31 (Figs 3 and 5).

\subsection{Relative air humidity}

If it is either too high or too low, air humidity disturbs the process by which the human body loses heat to the environment (e.g. Błażejczyk 2004; Araźny 2008). In the Arctic, high air humidity disturbs the process by which the human body loses heat to the environment by evaporation. In winter, air humidity relative to ice is at its highest because less water vapour is needed to saturate air over ice than air over water (Przybylak 2016).

For most of the year, FJL is influenced by humid maritime air masses carried by cyclonic action (Hisdal 1995). The annual average relative humidity in the modern period at $\mathrm{OH}$ was $85 \%$. In the annual course, the highest monthly average was recorded in August (92\%) and the lowest in March (80\%) (Table 5, Fig. 6).

Relative humidity is one of the most commonly used parameters in analysing air humidity in Arctic regions. Unfortunately, measurement is hampered by serious methodological difficulties. That is why the analysed measurement data from the historical expeditions are very incomplete 

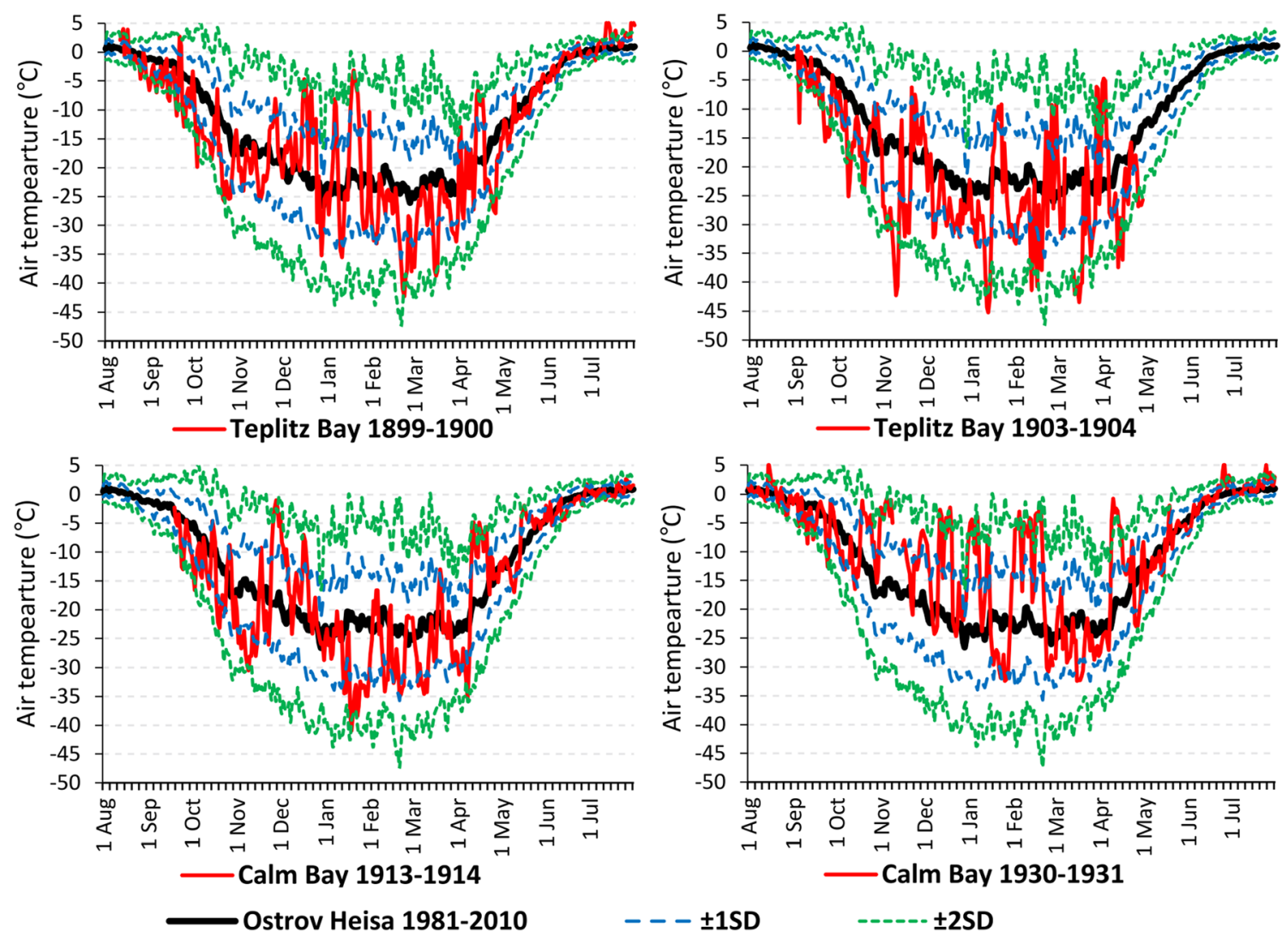

Fig. 4 Annual courses of average diurnal air temperature in the historical period (from Teplitz Bay and Calm Bay stations) and the contemporary period (Ostrov Heisa). Standard deviations ( \pm 1 SD and \pm 2 SD) were calculated for the contemporary period 1981-2010

(Fig. 6). Nevertheless, we cite this data with regard to determining the accepted level of physical activity (MHR). Diurnal and monthly average values of relative air humidity confirm the known dependence that, in warmer years, e.g. 1930/31, lower relative humidity is recorded and vice versa (Tables 3 and 5).

Table 4 Average monthly wind speed $\left(\mathrm{m} \mathrm{s}^{-1}\right)$ at $1.2 \mathrm{~m}$ a.g.l. at Ostrov Heisa $(\mathrm{OH})$ between 1981 and 2010, and mean differences between monthly values on Franz Josef Land for the historical period (for the Teplitz Bay [TB] and Calm Bay [CB] stations) and the contemporary period (Ostrov Heisa)

\begin{tabular}{|c|c|c|c|c|c|}
\hline $\begin{array}{l}\text { Station } \\
\text { Month }\end{array}$ & OH 1981-2010 & $\begin{array}{l}\text { TB (1899-1900) minus } \\
\text { OH (1981-2010) }\end{array}$ & $\begin{array}{l}\text { TB (1903-1904) minus } \\
\text { OH (1981-2010) }\end{array}$ & $\begin{array}{l}\text { CB (1913-1914) minus } \\
\text { OH (1981-2010) }\end{array}$ & $\begin{array}{l}\text { CB (1930-1931) minus } \\
\text { OH (1981-2010) }\end{array}$ \\
\hline Aug & 3.0 & & & & -0.7 \\
\hline Sep & 4.0 & -2.8 & 0.6 & & -0.2 \\
\hline Oct & 4.2 & -2.8 & 0.6 & 1.7 & 2.0 \\
\hline Nov & 4.1 & -1.2 & 1.7 & -0.3 & 2.9 \\
\hline Dec & 4.0 & -2.9 & 4.9 & 1.0 & 4.7 \\
\hline Jan & 4.2 & -2.4 & 2.0 & 0.0 & 3.8 \\
\hline $\mathrm{Feb}$ & 3.9 & -2.3 & 2.9 & 1.0 & 2.3 \\
\hline Mar & 3.8 & -2.2 & 0.5 & 0.1 & 0.7 \\
\hline Apr & 3.7 & -0.9 & -0.3 & 1.0 & -0.7 \\
\hline May & 3.4 & 0.6 & & -0.2 & 1.4 \\
\hline Jun & 3.3 & -0.9 & & 0.1 & -0.4 \\
\hline Jul & 3.1 & -1.0 & & -0.1 & 0.6 \\
\hline Oct-Apr & 4.0 & -2.1 & 1.7 & 0.6 & 2.2 \\
\hline
\end{tabular}



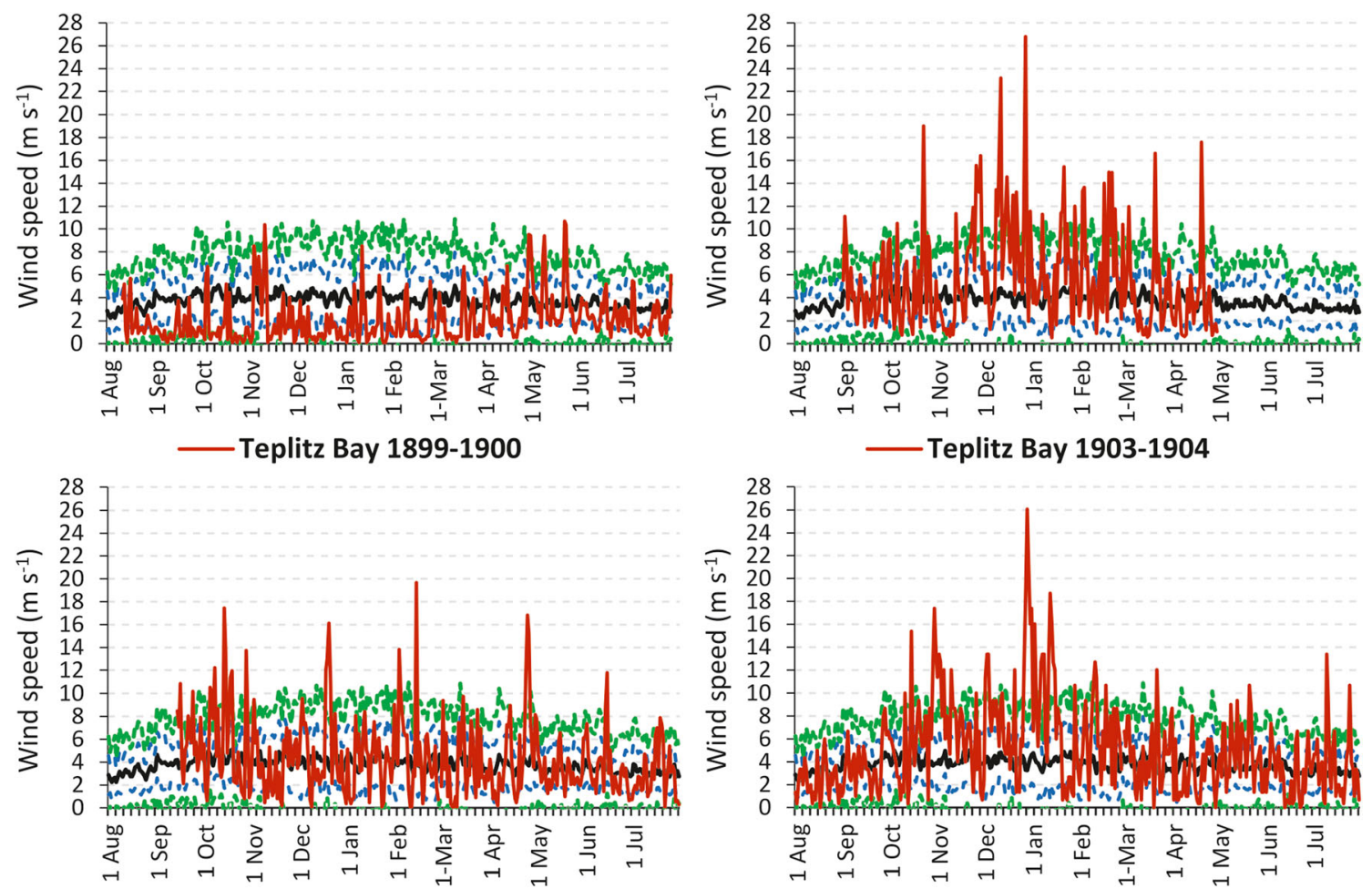

Calm Bay 1913-1914

Ostrov Heisa 1981-2010

$- -- \pm 1 S D$

\section{Calm Bay 1930-1931}

---- $\pm 2 S D$

Fig. 5 Annual courses of average diurnal wind speed at $1.2 \mathrm{~m}$ a.g.l. in the historical period (from the Teplitz Bay and Calm Bay stations) and the contemporary period (Ostrov Heisa); Standard deviations ( \pm 1 SD and \pm 2 SD) were calculated for the contemporary period 1981-2010

\subsection{Wind chill temperature (WCT)}

WCT is one of the best indices for characterising apparent cold in polar regions (www.ec.gc.ca/meteo-weather). WCT provides information on heat loss due from an uncovered face as a result of the effects of low air temperature and wind (Nelson et al. 2002) and the potential risk of frostbite at different times (Ducharme and Brajkovic 2002; Tikuisis and Osczevski 2003).

At $\mathrm{OH}$, in the modern period, the annual average for WCT was $-15.5^{\circ} \mathrm{C}$. In the annual course, the lowest monthly values $\left(-27.4\right.$ to $\left.-27.2{ }^{\circ} \mathrm{C}\right)$ occurred between January and March and the highest $\left(-0.3{ }^{\circ} \mathrm{C}\right)$ in July (Table 6). Analysis of mean daily values of $\mathrm{WCT}$ at $\mathrm{OH}$ showed, for example that
Table 5 Average monthly relative air humidity $(\%)$ at Ostrov Heisa $(\mathrm{OH})$ between 1981 and 2010, and mean differences between monthly values on Franz Josef Land for the historical period (for the Teplitz Bay [TB] and Calm Bay $[\mathrm{CB}]$ stations) and the contemporary period (Ostrov Heisa)

\begin{tabular}{lcclc}
\hline $\begin{array}{l}\text { Station } \\
\text { Month }\end{array}$ & OH 1981-2010 & $\begin{array}{l}\text { TB (1899-1900) minus } \\
\text { OH }(1981-2010)\end{array}$ & $\begin{array}{l}\text { TB (1903-1904) minus } \\
\text { OH (1981-2010) }\end{array}$ & $\begin{array}{l}\text { CB (1913-1914) minus } \\
\text { OH (1981-2010) }\end{array}$ \\
\hline Aug & 92 & & & -3 \\
Sep & 90 & 3 & & -1 \\
Oct & 86 & 9 & $2^{\mathrm{d}}$ & $0^{\mathrm{g}}$ \\
Nov & 84 & 8 & $0^{\mathrm{e}}$ & \\
Dec & 83 & $4^{\mathrm{a}}$ & & \\
Jan & 82 & & & \\
Feb & 82 & $9^{\mathrm{b}}$ & & \\
Mar & 80 & & & $-2^{\mathrm{h}}$ \\
Apr & 81 & & & $-2^{\mathrm{i}}$ \\
May & 85 & $3^{\mathrm{c}}$ & 4 & \\
Jun & 88 & 1 & 5 & $1^{\mathrm{f}}$ \\
Jul & 91 & -10 & &
\end{tabular}

-, no data; a, 19, 24 Dec; b, 4, 11-13, 26, 29 Feb; c, 3, 4 May; d, 13-15 Oct; e, 22-24 Nov; f, 30-31 Jul; g, 15-16, 28, 31 Oct; h, 1-2 Jun; i, 28-29 Jul 


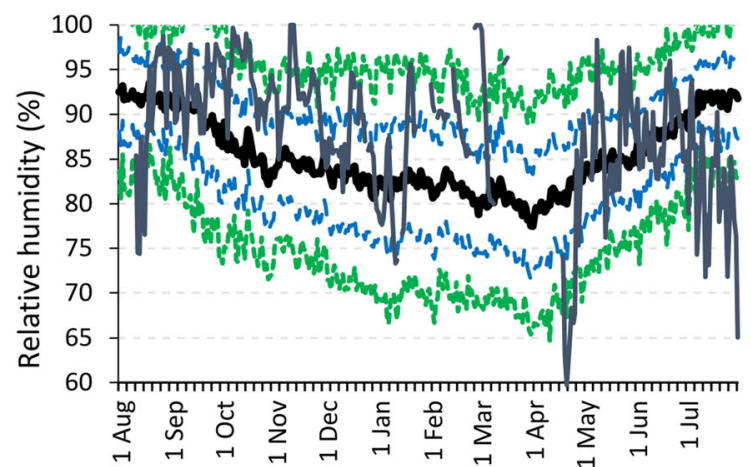

Teplitz Bay 1899-1900

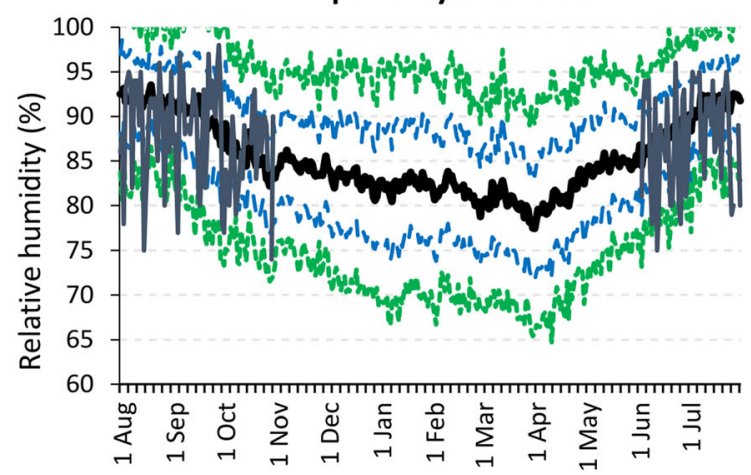

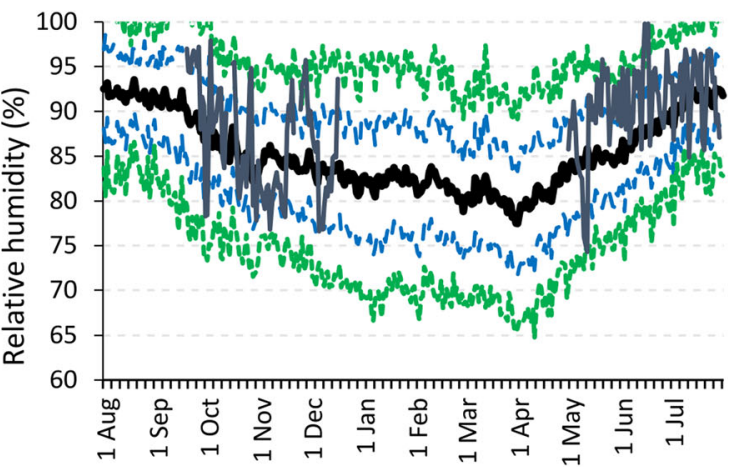

Calm Bay 1913-1914

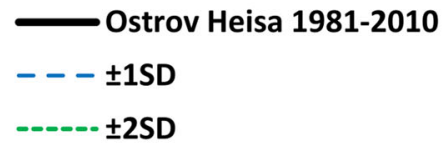

Calm Bay 1930-1931

Fig. 6 Annual courses of average diurnal relative humidity in the historical period (from the Teplitz Bay and Calm Bay stations) and the contemporary period (Ostrov Heisa). Standard deviations $( \pm 1 \mathrm{SD}$ and $\pm 2 \mathrm{SD}$ ) were calculated for the contemporary period 1981-2010

in winter and spring (when WCT values decreased to $49.8{ }^{\circ} \mathrm{C}$ ), there was a very high risk of frostbite after $2-$ 5 min (Table 2, Fig. 7).

During the 1903/1904 and 1913/1914 expeditions, lower WCT values were found than conditions observed nowadays. For example, in winter (Oct-Apr), they were 6.4 and $2.0{ }^{\circ} \mathrm{C}$ lower, respectively (Table 6). During these two expeditions, the worst conditions for humans $\left(-35.5^{\circ} \mathrm{C}\right)$ occurred in TB in December 1903 and were as much as $9.1{ }^{\circ} \mathrm{C}$ lower than the average conditions observed nowadays. In contrast, in the winter of the 1899-1900 and 1930/31 expeditions, the threat to human health was less than at present (by 1.3 and $4.0{ }^{\circ} \mathrm{C}$, respectively). The highest WCT occurred in CB in February 1931. In that month, the positive WCT anomaly was mainly

Table 6 Average monthly WCT $\left({ }^{\circ} \mathrm{C}\right)$ at Ostrov Heisa $(\mathrm{OH})$ between 1981 and 2010, and mean differences between monthly values on Franz Josef Land for the historical period (for the Teplitz Bay [TB] and Calm Bay [CB] stations) and the contemporary period (Ostrov Heisa [OH])

\begin{tabular}{|c|c|c|c|c|c|}
\hline $\begin{array}{l}\text { Station } \\
\text { Month }\end{array}$ & OH 1981-2010 & $\begin{array}{l}\text { TB (1899-1900) minus } \\
\text { OH (1981-2010) }\end{array}$ & $\begin{array}{l}\text { TB (1903-1904) minus } \\
\text { OH (1981-2010) }\end{array}$ & $\begin{array}{l}\text { CB (1913-1914) minus } \\
\text { OH (1981-2010) }\end{array}$ & $\begin{array}{l}\text { CB (1930-1931) minus } \\
\text { OH (1981-2010) }\end{array}$ \\
\hline Aug & -1.0 & & & & 1.0 \\
\hline Sep & -4.9 & 0.3 & $-4.8^{\mathrm{a}}$ & & -1.1 \\
\hline Oct & -14.2 & -2.1 & -4.5 & -4.3 & 0.9 \\
\hline Nov & -21.0 & 0.3 & -7.8 & -2.3 & $8.4^{\mathrm{d}}$ \\
\hline Dec & -26.4 & 9.1 & -9.1 & 5.2 & 5.6 \\
\hline Jan & -27.4 & 6.8 & -6.2 & -8.2 & 1.4 \\
\hline Feb & -27.2 & -3.3 & -6.7 & -4.5 & 10.2 \\
\hline Mar & -27.3 & -2.0 & $-6.4^{\mathrm{b}}$ & -2.5 & -4.2 \\
\hline Apr & -22.4 & 0.6 & $-3.9^{\mathrm{c}}$ & 2.3 & 5.5 \\
\hline May & -11.1 & -1.4 & & 0.6 & -1.9 \\
\hline Jun & -2.9 & 0.7 & & -0.7 & 1.4 \\
\hline Jul & -0.3 & 2.6 & & 0.2 & 0.8 \\
\hline Oct-Apr & -23.7 & 1.3 & -6.4 & -2.0 & 4.0 \\
\hline
\end{tabular}

-, no data; a, 1 Sep; b, 7-11 Mar; c, 30 Apr; d, 10-15 Nov 

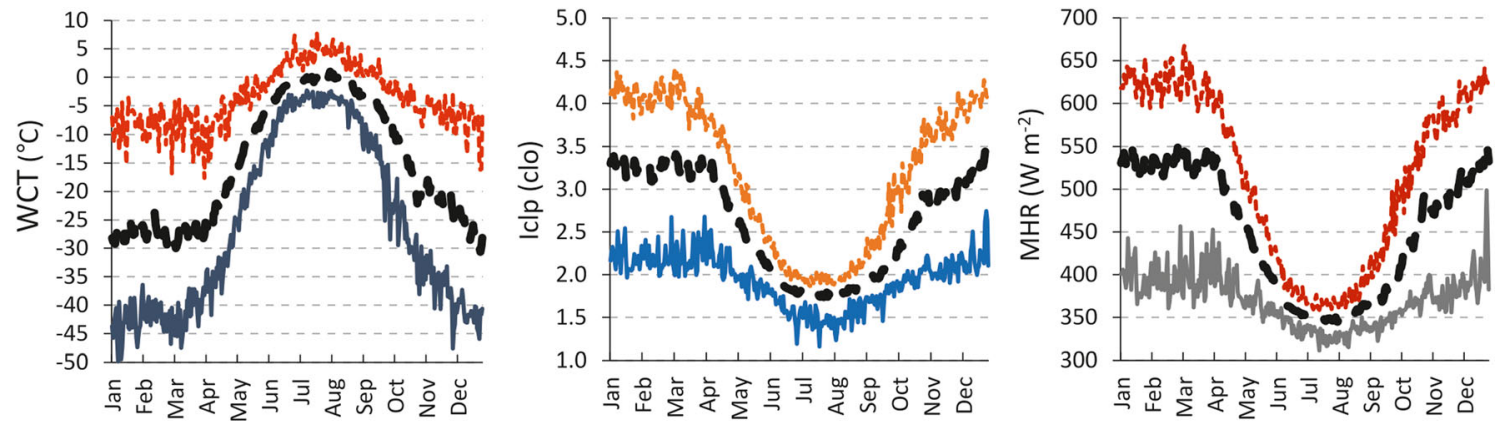

a) $-\infty \mathrm{m}-----\max \longrightarrow \min$

b) $-m-m$ min

c) $-m$ - ----max min

Fig. 7 Annual courses of average diurnal WCT, Iclp and MHR in Ostrov Heisa in 1981-2010. m, average diurnal value; max, highest diurnal average; min, lowest diurnal average

associated with a high air temperature anomaly. Average diurnal WCT values were within two standard deviations (2SD) of the 1981-2010 average (Fig. 8).

\subsection{Insulation predicted (Iclp)}

Clothing is the simplest defence against the negative effects of weather, particularly in polar regions (e.g. Svensson 1992; Araźny 2006; Araźny et al. 2010). In variable climatic conditions, the balance between the amount of heat gained and lost by the human body is maintained by adaptive thermoregulatory reflexes but also by the correct choice of clothing (Yan and Oliver 1996).

At $\mathrm{OH}$ in the modern period, clothes with high thermal insulation properties are necessary for optimal protection. Iclp values ranged from 1.8 clo (in July and August) to 3.3 clo (in January and March). The use of so-called transitional season clothing (thermal insulation 1.5-2.0 clo) was most appropriate from June to September (Table 7, Fig. 9). Light winter clothing (2.0-2.5 clo) should be used in May and October. However, for the rest of the year, for a comfortable level of thermal comfort, heavier winter clothing (>2.5 clo) should be used.
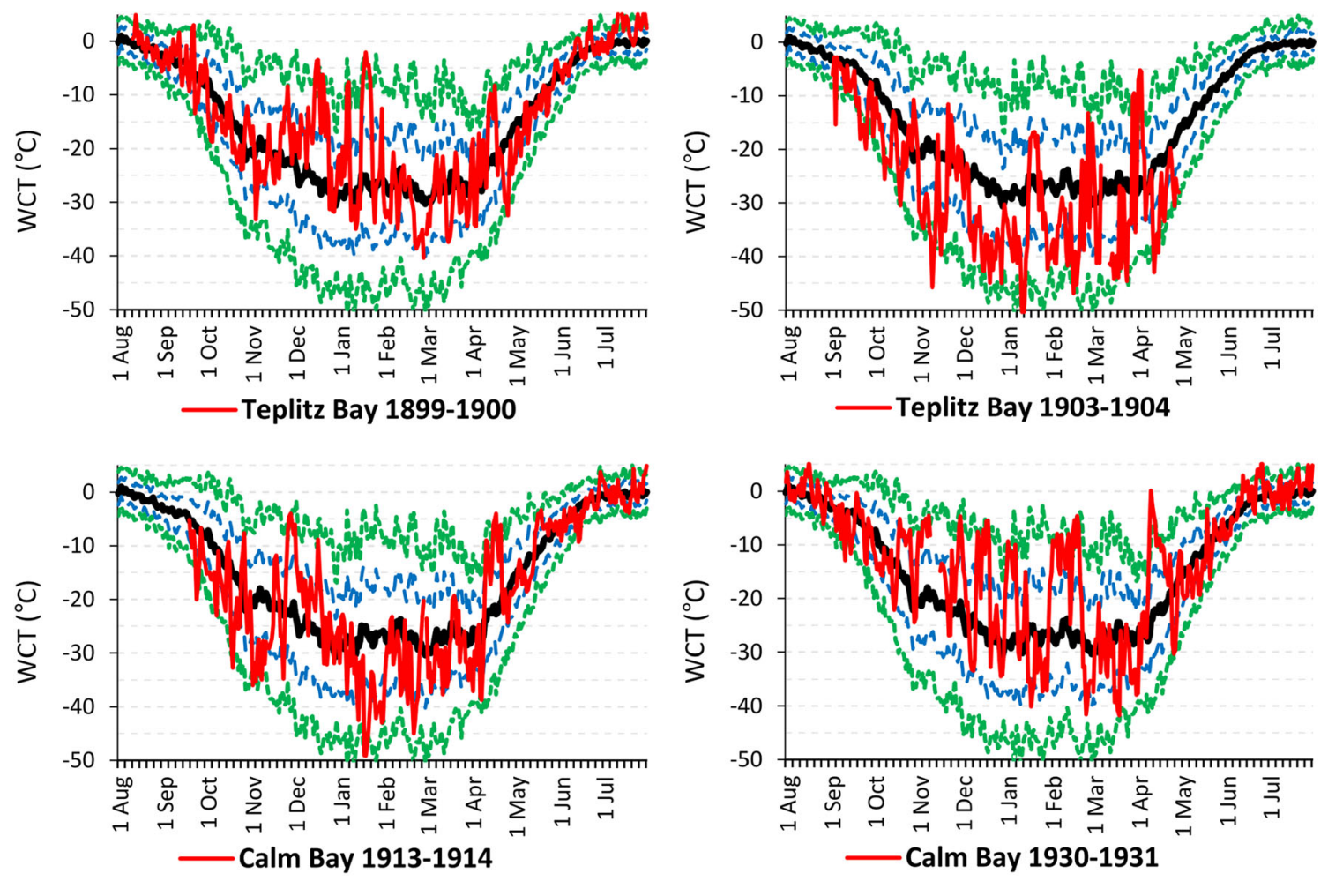

Ostrov Heisa 1981-2010

$- -- \pm 1 S D$ $- \pm 2 S D$

Fig. 8 Annual courses of average diurnal WCT in the historical period (from the Teplitz Bay and Calm Bay stations) and the contemporary period (Ostrov Heisa). Standard deviations ( $\pm 1 \mathrm{SD}$ and $\pm 2 \mathrm{SD}$ ) were calculated for the contemporary period 1981-2010 
Table 7 Average monthly Iclp (clo) values at Ostrov Heisa (OH) between 1981 and 2010, and mean differences between monthly values on Franz Josef Land for the historical period (for the Teplitz Bay [TB] and Calm Bay [CB] stations) and the contemporary period (Ostrov Heisa [OH])

\begin{tabular}{|c|c|c|c|c|c|}
\hline $\begin{array}{l}\text { Station } \\
\text { Month }\end{array}$ & OH 1981-2010 & $\begin{array}{l}\text { TB (1899-1900) minus } \\
\text { OH (1981-2010) }\end{array}$ & $\begin{array}{l}\text { TB (1903-1904) minus } \\
\text { OH (1981-2010) }\end{array}$ & $\begin{array}{l}\text { CB (1913-1914) minus } \\
\text { OH (1981-2010) }\end{array}$ & $\begin{array}{l}\text { CB (1930-1931) minus } \\
\text { OH (1981-2010) }\end{array}$ \\
\hline Aug & 1.8 & & & & -0.1 \\
\hline Sep & 2.0 & 0.0 & $0.3^{\mathrm{a}}$ & & 0.1 \\
\hline Oct & 2.5 & 0.2 & 0.2 & 0.2 & -0.1 \\
\hline Nov & 2.9 & 0.0 & 0.4 & 0.1 & $-0.5^{\mathrm{d}}$ \\
\hline Dec & 3.2 & -0.4 & 0.4 & -0.3 & -0.4 \\
\hline Jan & 3.3 & -0.3 & 0.3 & 0.5 & -0.1 \\
\hline Feb & 3.3 & 0.3 & 0.3 & 0.2 & -0.6 \\
\hline Mar & 3.3 & 0.2 & $0.4^{\mathrm{b}}$ & 0.2 & 0.2 \\
\hline Apr & 3.0 & 0.0 & $0.2^{\mathrm{c}}$ & -0.1 & -0.3 \\
\hline May & 2.4 & 0.1 & & 0.0 & 0.1 \\
\hline Jun & 1.9 & 0.0 & & 0.0 & -0.1 \\
\hline Jul & 1.8 & -0.2 & & 0.0 & -0.1 \\
\hline Oct-Apr & 3.1 & 0.0 & 0.3 & 0.1 & -0.3 \\
\hline
\end{tabular}

-, no data; a, 1 Sep; b, 7-11 Mar; c, 30 Apr; d, 10-15 Nov

In winter (Oct-Apr), during the 1899-1900 and 1913/14 expeditions, the required clothing insulation at $\mathrm{OH}$ was similar to conditions observed nowadays. During the 1903/04 expedition, the required clothing insulation was 0.3 clo higher than contemporary observations. In contrast, during the very warm expedition of 1930/31, comfort could be attained with

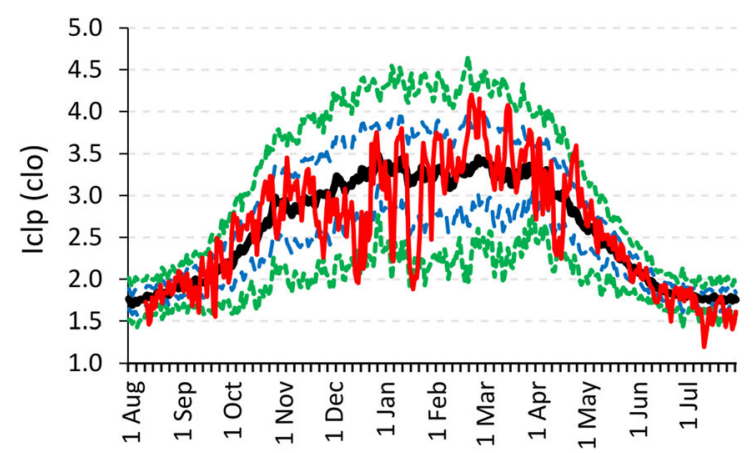

Teplitz Bay 1899-1900

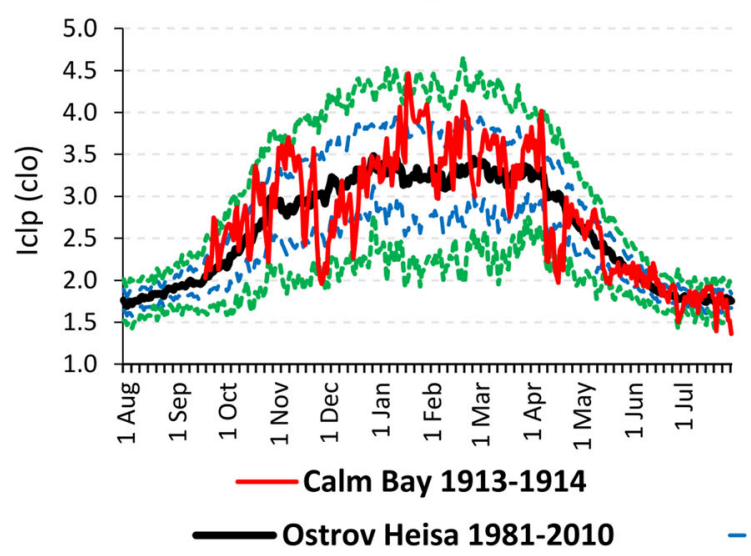

clothing of lower insulating parameters (by 0.3 clo) than in 1981-2010. It must be remembered that Iclp was calculated for a person moving outdoors at $4 \mathrm{~km} \mathrm{~h}^{-1}$. However, a standing person would require clothing of double the thermal thickness in order to maintain thermal comfort (Araźny 2008).

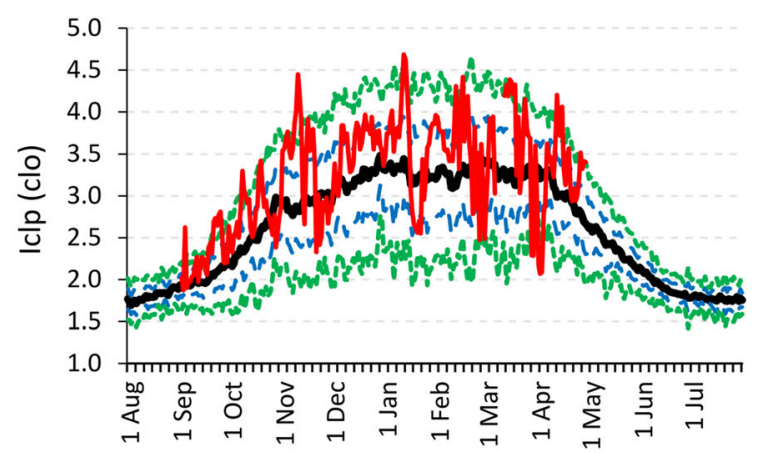

Teplitz Bay 1903-1904

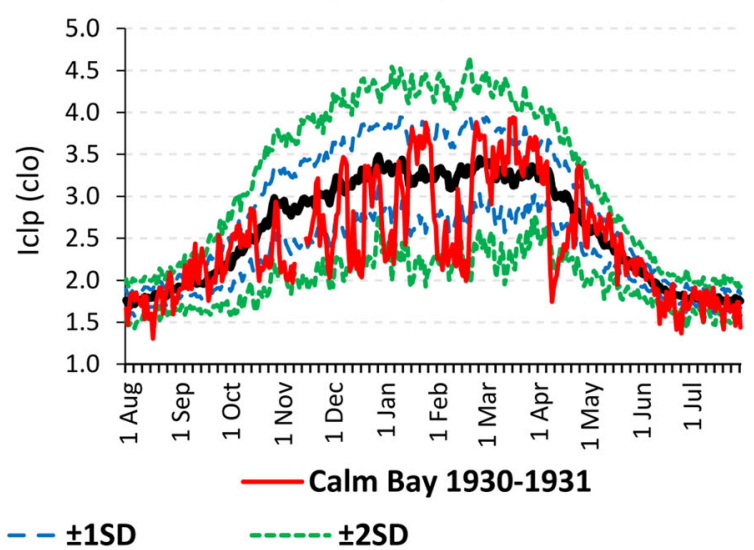

Fig. 9 Annual courses of average diurnal Iclp in the historical period (from the Teplitz Bay and Calm Bay stations) and the contemporary period (Ostrov Heisa). Standard deviations ( \pm 1 SD and \pm 2 SD) were calculated for the contemporary period 1981-2010 
Table 8 Average monthly MHR $\left(\mathrm{W} \mathrm{m}^{-2}\right.$ ) at Ostrov Heisa $(\mathrm{OH})$ between 1981 and 2010, and mean differences between monthly values on Franz Josef Land for the historical period (for the Teplitz Bay [TB] and Calm Bay [CB] stations) and the contemporary period (Ostrov Heisa $[\mathrm{OH}])$

\begin{tabular}{llcll}
\hline $\begin{array}{l}\text { Station } \\
\text { Month }\end{array}$ & OH 1981-2010 & $\begin{array}{l}\text { TB (1899-1900) minus } \\
\text { OH (1981-2010) }\end{array}$ & $\begin{array}{l}\text { CB (1913-1914) minus } \\
\text { OH (1981-2010) }\end{array}$ & $\begin{array}{l}\text { CB (1930-1931) minus } \\
\text { OH (1981-2010) }\end{array}$ \\
\hline Aug & 354.0 & & & -0.3 \\
Sep & 377.3 & 20.9 & $27.7^{\mathrm{c}}$ & 10.7 \\
Oct & 440.9 & 45.9 & $15.8^{\mathrm{d}}$ & $-11.6^{\mathrm{f}}$ \\
Nov & 488.4 & 12.6 & & \\
Dec & 523.5 & -33.8 & & \\
Jan & 529.3 & & & \\
Feb & 531.9 & $54.0^{\mathrm{a}}$ & & \\
Mar & 531.4 & & & $-8.2^{\mathrm{g}}$ \\
Apr & 500.2 & & -4.3 & -4.8 \\
May & 425.6 & $4.6^{\mathrm{b}}$ & 4.4 & \\
Jun & 367.3 & -0.7 & $1.3^{\mathrm{e}}$ & \\
Jul & 348.9 & -11.1 & & \\
\hline
\end{tabular}

-, no data; a, 4, 11-13, 26, 29 Feb; b, 3-4 May; c, 13-15 Oct; d, 23-24 Nov; e, 30-31 Jul; f, 15-16, 31 Oct; g, 1, 2 Jun; h, 28-29 Jul

\subsection{Accepted level of physical activity (MHR)}

In certain meteorological conditions, MHR values may not represent a burden on the heart, i.e. those below 90 beats per minute (Błażejczyk and Kunert 2011). As previously mentioned, exceeding this limit may be dangerous to the human body.

MHR calculations on FJL were done on the assumption of moderate physical activity (walking at $4 \mathrm{~km} / \mathrm{h}$ ). In the modern period at $\mathrm{OH}$, average monthly values $\left(>350 \mathrm{~W} \mathrm{~m}^{-2}\right)$ indicate that thermal and humidity conditions allow for intensive effort throughout the year (Table 8).

Calculating MHR requires air humidity data, which are largely incomplete for the historical periods (Table 5, Fig. 10). By comparing shorter periods, such as the monthly averages for historical and contemporary periods, it is possible to conclude that MHR conditions were similar in the two periods.
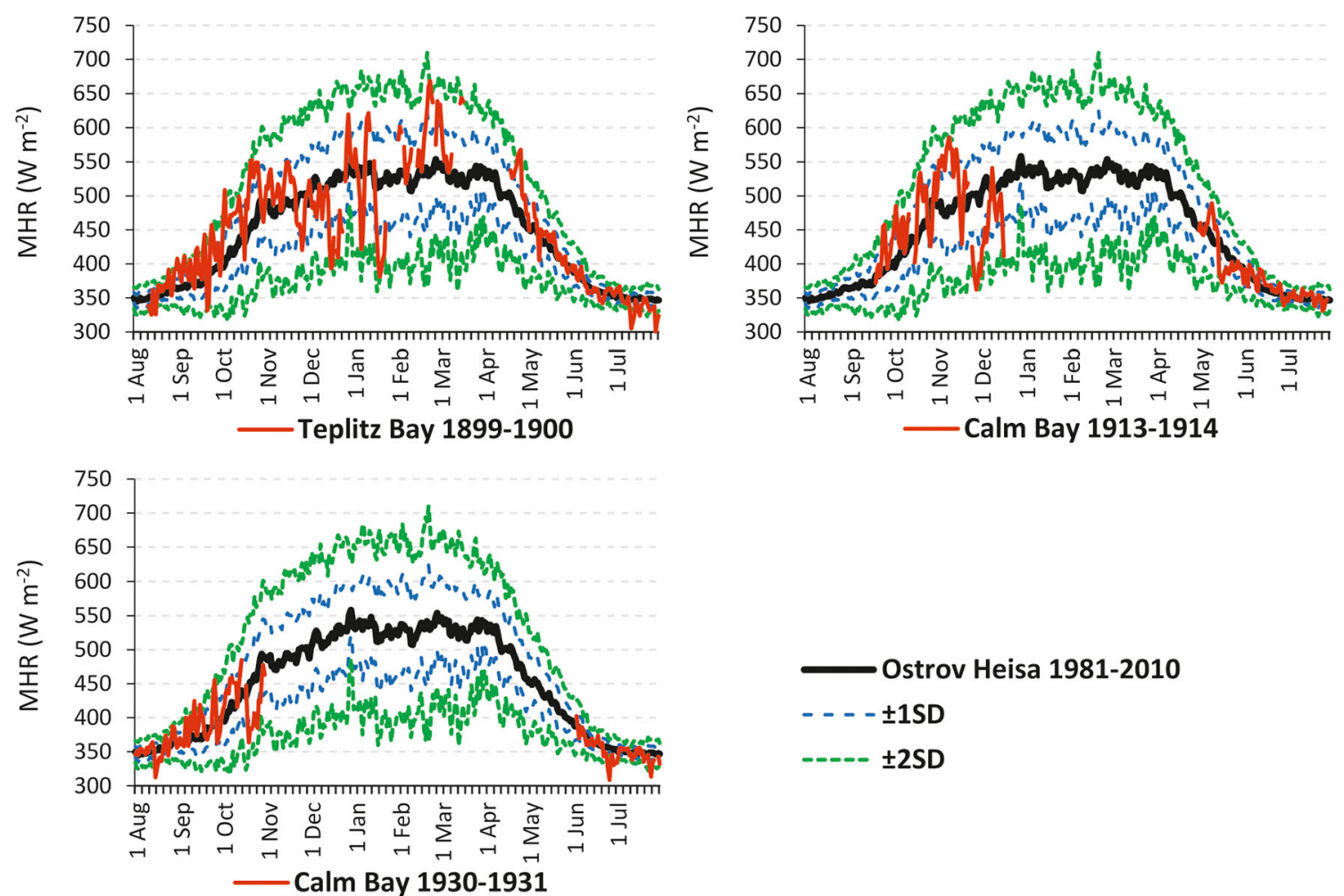

Fig. 10 The course of average diurnal MHR in the historical period (from the Teplitz Bay and Calm Bay stations) and the contemporary period (Ostrov Heisa). Standard deviations ( \pm 1 SD and \pm 2 SD) were calculated for the contemporary period 1981-2010 


\section{Discussion}

From the end of the nineteenth century, air temperature increased more sharply in the Arctic that elsewhere on Earth (e.g. Budyko 1974; Przybylak 2000, 2007, 2016; Alekseev 2003; Overland et al. 2004; IPCC 2013). For example, Svalbard (land data) in the period 1865-1920 was markedly colder than nowadays (1981-2010) by about $3{ }^{\circ} \mathrm{C}$ (Przybylak et al. 2016). In approximately the last 140 years, there have been two periods of significant temperature increases in the Arctic. The first began in around 1918-1920 and lasted until 1938 and has been called the '1930s warming' (Bengtsson et al. 2004). Other works have referred to this period as the 'Early Twentieth Century Warming' (ETCW, Brönnimann 2009) or the 'Early Twentieth Century Arctic Warming' (ETCAW, Wegmann et al. 2017, 2018). Our results confirm the observations for the last expedition from the historical study period in 1930/1931. These years covered the warmest part of the ETCW (Table 3, Fig. 4). In turn, the second increased warming of the Arctic began around 1980 (Johannessen et al. 2004) or according to Przybylak (2007) in about the mid-1990s. Changes in overall atmospheric circulation have long been believed to have been the cause of the ETCW (e.g. Scherhag 1937). As the modern climate warming (since 1975) has progressed in a largely similar manner to the progression of the ETCW (Wood and Overland 2010; Semenov and Latif 2012), there has been renewed interest in the insufficiently well-explained causes of the ETCW using the latest research methods, including, primarily, climate models. An analysis of the literature shows that the cause of such a significant warming in the present period is still not clear. There is even controversy over whether the main factors in the process are natural or anthropogenic, although the decided majority of researchers assign a greater role to natural factors (Bengtsson et al. 2004; Semenov and Latif 2012). It would appear that the greatest differences of opinion on the causes of the ETCW are to be found in works presenting climate models (see, e.g. Shiogama et al. 2006; Suo et al. 2013), which is an excellent illustration of the stillinsufficient knowledge of the mechanisms governing the Arctic Climate System.

Compared to the data for air temperature, there are significantly fewer reliable data available for air humidity, wind speed and wind direction for the historical period (the end of the nineteenth century and early twentieth century). This is because of, among other things, the significant influence that wind measurements have on local conditions and difficulties involved in taking reliable measurements of air humidity (Vizi 2008; Wyszyński and Przybylak 2014). In addressing the issue of wind directions and velocity in the Canadian Arctic in the mid-nineteenth century, Vizi (2008) found that they depend heavily on local conditions (ships most often chose secluded places deep in fjords or bays to winter). According to that author, this makes it impossible to reliably know what anemological conditions are representative for this area. Meanwhile, Wyszyński and Przybylak (2014) stated that 'the literature does not offer any detailed studies of the humidity of air in the Arctic during the early instrumental times, due to the fact that it was extremely difficult to take reliable measurements of atmospheric humidity in the polar regions with negative air temperatures prevailing most of the year'. Recent years have brought no new studies on this matter to add to those mentioned above. Wyszyński and Przybylak (2014) presented the most complete work on hygrometric conditions (water vapour pressure and relative humidity) for the entire Arctic in the historical period, but this was based only on data collected during the 1st International Polar Year 1882/1883. In that year (September 1882-July 1883), it was calculated that the relative humidity was on average about $2-6 \%$ higher than nowadays. The measurement difficulties related to air humidity have meant that the empirical data for this element that were collected during four polar expeditions from the historical period and used in this article contain many gaps (Table 5). In the Arctic in the modern period, WCT has only been analysed at higher latitudes of North America (Keimig and Bradley 2002; Mekis et al. 2015; Howarth and Laird 2017) and in the Norwegian Arctic (Araźny 2008). The results of these studies in the Arctic confirm that WCT values towards the end of the twentieth and beginning of the twenty-first century have been systematically increasing, which indicates greater apparent warmth for humans. However, WCT has not yet been analysed for historical times in the Arctic area.

For the Arctic area in the historical period, synthetic information about Iclp is only available for the first IPY period (Araźny 2010). A comparison of the historical period (188283) against the period 1971-2000 has only been made for the Jan Mayen station (Spitsbergen). During the first IPY, the thermal insulation properties of clothing for a person in motion had to be 0.1 clo higher than they were at the end of the twentieth century. In terms of the demand for clothing with optimal insulation properties for a person in motion during the first MRP in, for example the winter months, heavy Arctic clothing was required (Araźny 2010). In the Arctic, Iclp has only been analysed in the Atlantic region for 1971-2000 by Araźny (2006, 2008). He concluded a gradual decrease in the required clothing insulation in the Norwegian Arctic in the study period.

To calculate MHR alongside thermal conditions, information about air humidity is necessary, which is difficult to find and often not complete in the historical periods. This index has not been analysed thus far for historical times in the Arctic.

\section{Conclusions}

Currently, analyses of biometeorological conditions present the real human physiological processes and loads experienced 
in various environments. These employ human heat balance models which describe all the complex mechanisms of the mechanisms of heat transfer and heat exchange of the human body (Błażejczyk 2003, 2004). These models have been used to create, for example a new index, Universal Thermal Climate Index-UTCI (Błażejczyk et al. 2012). In the current research, these tools could not be used because the required input data, including solar radiation and cloudiness values, were not available. The availability of meteorological data for the historical period allows biometeorological indices mainly based on air temperature and wind speed (e.g. WCT and Iclp) to be calculated.

The data analyses for FJL during the three oldest expeditions (1899-1914) lead us to conclude that the biometeorological conditions in the study area were more harsh to humans than in the modern period (1981-2010) or similarly harsh. In contrast, during the 1930/1931 expedition (the last analysed period), in the ETCW, conditions were clearly more favourable.

Summarising the key results of the analyses conducted in the study, it can be concluded that on FJL:

- Air temperature in 1899-1914 during three expeditions was $1.8-4.6{ }^{\circ} \mathrm{C}$ lower than the modern period in winter (Oct-Apr). However, during the 1930/31 expedition it was $4.6^{\circ} \mathrm{C}$ warmer than the years $1981-2010$. Our results relate to what has been called the '1930s warming', referred to by various authors in the literature as the ETCW or the ETCAW.

- Wind speeds in three expeditions (1903/1904, 1913/1914 and 1930/1931) were $0.6-2.2 \mathrm{~m} \mathrm{~s}^{-1}$ higher than at present. Decidedly weaker winds than at present (by $2.1 \mathrm{~m} \mathrm{~s}^{-1}$ ) were recorded during the 1899-1900 expedition.

- WCT values in the 1903/1904 and 1913/1914 expedition years were lower (by 6.4 and $2.0^{\circ} \mathrm{C}$, respectively) than at present. In the winter (Oct-Apr) of the 1899-1900 and 1930/31 expeditions, the threat to human health was less than at present (by 1.3 and $4.0^{\circ} \mathrm{C}$, respectively).

- The meteorological conditions of FJL show that the required clothing insulation in 1899-1900 and 1913/14 was similar to the modern period. During 1903/04, an increase of 0.3 clo in clothing insulation required to obtain thermal comfort was recorded, while in 1930/31, there was a decrease (of 0.3 clo) relative to the period 19812010.

- Calculating accepted level of physical activity requires data on air humidity conditions, which for the historical period on FJL have large gaps due to difficulties with measurement. For this reason, information on MHR is scarce. Despite this, based on the collected data for 1899-1931, it can be concluded that thermal and humidity conditions made intensive effort possible throughout the year.
This article is one of the first in the literature to present an analysis of biometeorological conditions in the Arctic in historical periods. The Department of Meteorology and Climatology of Nicolaus Copernicus University has a sizeable database of early instrumental data for the Arctic region, the Historical Arctic Database (HARD 2.0, http://www.hardv2. prac.umk.pl/), and work on climate reconstructions of the region is ongoing. This line of application of the data, i.e. the historical bioclimatology of the Arctic, will continue to be developed in the near future.

Funding information The research work of Andrzej Araźny and Przemyslaw Wyszyński was supported by a grant entitled "Variability of the Russian Arctic and Subarctic Climate in the Last Three Hundred Years" funded by the National Science Centre, Poland (Decision No. DEC-2012/07/B/ST10/04002). Rajmund Przybylak acknowledges funding from the National Science Centre, Poland (Grant No. 2015/19/ B/ST10/02933 entitled "Causes of the early 20th century Arctic warming").

OpenAccessThis article is distributed under the terms of the Creative Commons Attribution 4.0 International License (http://creativecommons.org/ licenses/by/4.0/), which permits unrestricted use, distribution, and reproduction in any medium, provided you give appropriate credit to the original author(s) and the source, provide a link to the Creative Commons license, and indicate if changes were made.

Publisher's note Springer Nature remains neutral with regard to jurisdictional claims in published maps and institutional affiliations.

\section{References}

ACIA (2005) Arctic climate impact assessment. Cambridge University Press, Cambridge

Alekseev GV (2003) Issledovaniya izmenenij klimata Arktiki v XX stoletii. [Studies of climate change in the Arctic in the twentieth century]. Trudy AANII 446:6-21

Araźny A (2006) Variability of the predicted insulation index of clothing in the Norwegian Arctic for the period 1971-2000. Pol Polar Res 27(4):341-357

Araźny A (2008) Bioklimat Arktyki Norweskiej i jego zmienność w okresie 1971-2000. [Bioclimatic conditions and their variability in the Norwegian Arctic for the period 1971-2000]. Wyd Uni Mikołaja Kopernika, Toruń

Araźny A (2010) Biometeorological conditions in the Arctic during the First International Polar Year, 1882-1883. Bull Geogr Phys Geogr Ser 3:47-64

Araźny A, Migała K, Sikora S, Budzik T (2010) Meteorological and biometeorological conditions in the Hornsund area (Spitsbergen) during the warm season. Pol Polar Res 31(3):217-238. https://doi. org/10.2478/v10183-010-0002-4

Bengtsson L, Semenov VA, Johannessen OM (2004) The early twentiethcentury warming in the Arctic - a possible mechanism. J Clim 17(20):4045-4057. https://doi.org/10.1175/1520-0442(2004) 017<4045:TETWIT>2.0.CO;2

Błażejczyk K (2003) Biotermiczne cechy bioklimatu Polski. [Biothermal features of the climate of Poland]. Przegląd Geogr 75(4):535-554

Błażejczyk K (2004) Bioklimatyczne uwarunkowania turystyki i rekreacji w Polsce. [Bioclimatic principles of recreation and tourism in Poland]. Prace Geograficzne IGIPZ PAN, 192 
Błażejczyk K (2017) Bioklima 2.6. computer program-http://www.igipz. pan.pl/Bioklima-zgik.html

Błażejczyk K, Kunert A (2011) Bioklimatyczne uwarunkowania rekreacji i turystyki w Polsce. [Bioclimatic principles of recreation and tourism in Poland]. Polish Academy of Sciences, Monographies 13, Warsaw

Błażejczyk K, Epstein Y, Jendritzky G, Staiger H, Tinz B (2012) Comparison of UTCI to selected thermal indices. Int $\mathrm{J}$ Biometeorol 56(3):515-535

Bottema M (2000) A method for optimisation of wind discomfort criteria. Build Environ 35:1-18

Brönnimann S (2009) Early twentieth-century warming. Nat Geosci 2: 735-736. https://doi.org/10.1038/ngeo670

Brönnimann S, Annis J, Dann W, Ewen T, Grant AN, Griesser T, Krähenmann S, Mohr C, Scherer M, Vogler C (2006) A guide for digitising manuscript climate data. Clim Past 2:137-144. https://doi. org/10.5194/cp-2-137-2006

Budyko MI (1974) Izmeneniya klimata. [Climate change]. Gidrometeoizdat, Leningrad

Burton AC, Edholm OG (1955) Man in a cold environment. E. Arnold Publ, London

Cagni U (1903) Osservazioni scientifiche eseguite durante la Spedizione Polare di S.A.R. Luigi Amedeo di Savoia: Duca Degli Abruzzi, 1899-1900. [Scientific observations made during the Polar Expedition of S.A.R. Luigi Amedeo di Savoia: Duca Degli Abruzzi, 1899-1900]. Milano, Ulrico Hoepll, data:223-415

Capelotti PJ (2009) Further to the death of Sigurd B. Myhre at Camp Abruzzi, Rudolf Island, Franz Josef Land, May 16, 1904, during the Ziegler Polar Expedition. Polar Res 28(3):463-467. https://doi.org/ 10.1111/j.1751-8369.2008.00089.x

Capelotti PJ (2016) The Greatest Show in the Arctic: the American Exploration of Franz Josef Land, 1898-1905. American Exploration and Travel Series. University of Oklahoma Press

Compo GP, Whitaker JS, Sardeshmukh PD, Matsui N, Allan RJ, Yin X, Gleason BE, Vose RS, Rutledge G, Bessemoulin P, Brönnimann S, Brunet M, Crouthamel RI, Grant AN, Groisman PY, Jones PD, Kruk MC, Kruger AC, Marshall GJ, Maugeri M, Mok HY, Nordli Ø, Ross TF, Trigo RM, Wang XL, Woodruff SD, Worley SJ (2011) The twentieth century reanalysis project. Q J R Meteorol Soc 137:128. https://doi.org/10.1002/qj.776

Ducharme MB, Brajkovic D (2002) Wind chill and the development of frostbite in the face. 15th Conf. on Biomet/Aerology and 16th Congress of Biomet, October 2002, Kansas City. KS, Amer Meteor Soc, CD-ROM, 6B.1

Fourt J, Hollies NRS (1970) Clothing. Comfort and function, M. Dekker Inc., New York

Gavhed D (2003) Human responses to cold and wind. Arbete och Hälsa 2003:4, National Institute for Working Life, Stockholm

Geographisches Handbuch (1909) Albert Scobel, I Band, Bielefeld und Leipzig

Glazovskij AF (1995) Geographical position and general characteristics of the Franz Josef Land archipelago. In: Barr S (ed) Franz Josef Land. Norsk Polarinstitutt, Oslo, pp 8-10

Gregory S (1973) Statistical methods and the geographer. Longman

Grosswald MG, Krenke AN, Vinogradov ON, Markin VA, Psareva TV, Razumeyko NG, Sukhodrovskiy VL (1973) Oledenenie Zemli Franca-Josefa. [Glaciation of Franz Josef Land]. Nauka

Hisdal V (1995) Climate. In: Barr S (ed) Franz Josef Land. Norsk Polarinstitutt, Oslo, pp 11-14

Howarth ME, Laird NF (2017) Intraseasonal variations of winter wind chill temperatures across Canada and the United States. J Appl Meteorol Climatol 56(11):2951-2962. https://doi.org/10.1175/ JAMC-D-16-0394.1

Intergovernmental Panel on Climate Change (2013) Climate Change 2013: the physical science basis. Working group II contribution to the IPCC 5th assessment report
Johannessen OM, Bengtsson L, Miles MW, Kuzmina SI, Semenov VA, Alekseev GV, Andrei P, Nagurnyi AP, Victor F, Zakharov VF, Bobylev L, Pettersson L, Hasselmann K, Cattle HP (2004) Arctic climate change: observed and modelled temperature and sea ice variability. Tellus A 56(4):328-341

Keimig FT, Bradley RS (2002) Recent changes in wind chill temperatures at high latitudes in North America. Geophys Res Lett 29:4-1-4-4. https://doi.org/10.1029/2001g1013228

Krawczyk B (2000) Izolacyjność cieplna odzieży jako wskaźnik oceny warunków biotermicznych. [Effective clothing insulation index as a basis of evaluation of thermal conditions]. Balneologia Polska 43(12):105-111

Lubinski DJ, Forman SL, Miller GH (1999) Holocene glacier and climate fluctuations on Franz Josef Land, Arctic Russia, $80^{\circ} \mathrm{N}$. Quat Sci Rev 18:85-108

Lvov BC (ed) (1933) Meteorological Observations of the Polar Station at Franz Josef Land, Calm Bay, Wintering of 1930-1931. Central administration of the Hydrometeorological Service of the U. S. S. R., Central Geophysical Observatory, Section of Polar and High Altitude Observations of the Institute of Climatology, Leningrad

Maciejczyk M, Araźny A, Opyrchał M (2017) Changes in aerobic performance, body composition and physical activity in polar explorers during a year-long stay at the polar station in the Arctic. Int J Biometeorol 61(4):669-675. https://doi.org/10.1007/s00484-0161244-6

Mekis É, Vincent LA, Shephard MW, Zhang X (2015) Observed trends in severe weather conditions based on humidex, wind chill, and heavy rainfall events in Canada for 1953-2012. Atmos-Ocean 53:383397. https://doi.org/10.1080/07055900.2015.1086970

Milewskij WJ (1960) Effektiwnyje tiempieratury na jewropejskoj tierritorii SSSR. [Effective temperatures in the European territory of the USSR] In: Woprosy prikładnoj klimatołogii, Leningrad

Nelson CA, Tew M, Phetteplace G, Schwerdt R, Maarouf A, Osczevski R, Bluestein M, Shaykewich J, Smarsh D, Derby JC, Petty RC, Berger M, Quayle RG, Santee WR, O'Lenic E, Lupo AR, Browne K (2002) Joint development and implementation by the United States and Canada of a new Wind Chill Temperature (WCT) index. In: 15th International Conference on Biometeorology and Aerobiology, Kansas City:172-176

Osczevski RJ (2000) Windward cooling: an overlooked factor in the calculation of wind chill. Bull Am Meteorol Soc 81:2975-2978

Overland JE, Spillane MC, Percival DB, Wang M, Mofjeld HO (2004) Seasonal and regional variation of pan-arctic surface air temperature over the instrumental record. J Clim 17(17):3263-3282. https://doi. org/10.1175/1520-0442(2004)017<3263:SARVOP>2.0.CO;2

Parsons K (2003) Human thermal environments, 2nd edn. Taylor and Francis, London

Peters WJ, Fleming JA (1907) Section C: meteorological observations and compilations. In: Fleming JA (ed) The Ziegler Polar expedition 1903-05. Anthony Fiala Commander. National Geographic Society, Washington, pp 369-487

Przybylak R (2000) Temporal and spatial variation of surface air temperature over the period of instrumental observations in the Arctic. Int $\mathrm{J}$ Climatol 20(6):587-614

Przybylak R (2007) Recent air-temperature changes in the Arctic. Ann Glaciol 46(1):316-324

Przybylak R (2016) The Climate of the Arctic. Second edition, Atmospheric and Oceanographic Sciences Library 52, Springer, Heidelberg/New York/Dordrecht/London

Przybylak R, Wyszyński P (2017) Air temperature in Novaya Zemlya Archipelago and Vaygach Island from 1832 to 1920 in the light of early instrumental data. Int J Climatol 37:3491-3508. https://doi. org/10.1002/joc.4934

Przybylak R, Vizi Z, Wyszyński P (2010) Air temperature changes in the Arctic from 1801 to 1920 . Int J Climatol 30:791-812. https://doi. org/10.1002/joc. 1918 
Przybylak R, Wyszyński P, Vízi Z, Jankowska J (2013) Atmospheric pressure changes in the Arctic from 1801 to 1920. Int J Climatol 33:1730-1760. https://doi.org/10.1002/joc.3546

Przybylak R, Wyszyński P, Nordli Ø, Strzyżewski T (2016) Air temperature changes in Svalbard and the surrounding seas from 1865 to 1920. Int J Climatol 36:2899-2916. https://doi.org/10.1002/joc4527

Scherhag R (1937) Die Erwärmung der Arktis. ICES J Mar Sci 12:263276

Semenov VA, Latif M (2012) The early twentieth century warming and winter Arctic sea ice. Cryosphere 6:1231-1237

Serreze MC, Barry RG (2014) The Arctic climate system, 2nd edn. Cambridge University Press, Cambridge

Shilovtseva O, Romanenko F (2016) Climate change of Franz Josef Land in the XX-XXI centuries, EGU general assembly conference abstracts. Vol. 18, EGU general assembly 2016, 17-22 April, 2016 in Vienna Austria, id. EPSC2016-9811

Shiogama H, Nagashima T, Yokohata T, Crooks SA, Nozawa T (2006) Influence of volcanic activity and changes in solar irradiance on surface air temperatures in the early twentieth century. Geophys Res Lett 33:L09702

Suo L, Ottera OH, Bentsen M, Gao Y, Johannessen OM (2013) External forcing of the early 20th century Arctic warming. Tellus A 65:20578

Svensson TG (1992) Clothing in the Arctic: a means of protection, a statement of identity. Arctic 45(1):62-73
Tikuisis P, Osczevski RJ (2003) Facial cooling during cold air exposure. Bull Am Meteorol Soc 84:927-933

Vise VY (1933) Meteorological observations of the Sedov Polar Expedition. Vol. II. Observations at Calm Bay, Franz-Joseph Land 1913-1914. Materials for the study of the Arctic. No. 2. USSR Arctic Institute, Leningrad

Vizi Z (2008) Variability of the American Arctic climate in the 19th century. PhD thesis, Nicolaus Copernicus University in Torun

Wegmann M, Brönnimann S, Compo GP (2017) Tropospheric circulation during the early twentieth century Arctic warming. Clim Dyn 48: 2405-2418. https://doi.org/10.1007/s00382-016-3212-6

Wegmann M, Orsolini Y, Zolina O (2018) Warm Arctic-cold Siberia: comparing the recent and the early 20th-century Arctic warmings. Environ Res Lett 13. https://doi.org/10. 1088/1748-9326/aaa0b7

Williams M (2005) Franz Josef Land. In: Nuttall M (ed) Encyclopedia of the Arctic, vol Vol. I (A-F). Routledge, New York-London, pp 674675

Wood KR, Overland JE (2010) Early 20th century Arctic warming in retrospect. Int J Climatol 30:1269-1279

Wyszyński P, Przybylak R (2014) Variability of humidity conditions in the Arctic during the first International Polar Year, 1882-83. Polar Res 33:23896. https://doi.org/10.3402/polar.v33.23896

Yan YY, Oliver JE (1996) The Clo: a utilitarian unit to measure weather/ climate comfort. Int J Climatol 16(9):1045-1056 